\title{
Marshall Rosenberg's non-violent communication as the language of life in a doctor-patient relationship
}

\section{Abstract}

The aim of the article is to present Marshall Bertrand Rosenberg's concept of non-violent communication (NVC) and usefulness in the doctor-patient relationship. M. B. Rosenberg's concept of NVC was based on the assumption that a person's natural ability is empathy directed towards other people and towards themselves. However, our culture suppresses these natural abilities. The language offers many expressions that block natural compassion because they are overfilled with moral judgments, judging comparisons, punishments, arousing feelings of guilt or shame. The author of NVC proposes a four-phase model of empathic non-violent and non-manipulative communication, which is the basis for changes in the thought process: observing without judging, recognising, relating the feelings currently experienced to needs (values) and formulating concrete requests instead of demands.

Palliat Med Pract 2020; 14, 4: 285-289

Key words: non-violent communication, empathy, doctor-patient communication, feelings, needs

\section{Introduction}

The conviction that long experience of working with patients is enough to learn how to communicate understandably and deal with difficult situations is not borne out by reality. Physicians' lack of knowledge of the assumptions necessary for the use of good communication at the beginning of professional life and lack of development in this respect result in committing communication errors that over the years of work reinforce, strengthen and ultimately may lead to professional burnout and the belief that the patients they communicate with are extremely difficult [1]. Nowaczyk et al. proved that the effectiveness of physicians' communication decreases with the length of service [2].
Sören Kierkegaard wrote: "If I want to succeed by bringing a person to a certain goal, I must first find out where he is and start right there. He who can not do that, fools himself when he thinks he can help others. To help someone I must understand more than he does, but first and foremost understand what he understands. If I can not, my greater understanding does not help him at all. Do I still want to show how much I can, it's because I'm vain and proud and really want to be admired by the other instead of helping him. All genuine helpfulness begins with humility for the one I want to help and I have to understand that helping is not to dominate, but to serve. If I can not do this, I can not help anyone either" [3].

"Educating the mind without educating the heart is no education at all," said Aristotle in the fourth

\footnotetext{
Address for correspondence:

Hanna Gęsińska

Nicolaus Copernicus University in Toruń, Collegium Medicum in Bydgoszcz, Poland

Marymoncka Jagiellońska 13/15, 85-067 Bydgoszcz

e-mail: hannagesinska1@cm.umk.pl
} 
century BC. Marshall Bertram Rosenberg, an American psychologist, met this truth. In the 1960s, he proposed the non-violent communication process to implement the decision on non-violence at all levels of our structure: in thought, word and action [4]. Because the term NVC is trademarked and can only be used by NVC trainers certified by an organisation founded by M. B. Rosenberg - Center for Nonviolent Communiction (CNVC), it is also often called the language of life or the language of the heart. The use of the language of life requires a change in thinking as a prerequisite for correct communication.

Doctors are aware of the existence of verbal violence, but not everyone knows that the manifestations of violence are also casting the responsibility on others, moral judgment, comparison, punishment, or forcing. More people can get rid of physical violence, but cannot give up the language of judgements, threats or demands. Similarly, many more people will be able to practice their language than to train their mind or heart so as to persevere in a decision of non-violence [4]. Our words reflect our thoughts, what we think and how we think. According to Indian philosopher, Jiddu Krishnamurti, making observations, while refraining from judgments, proves the highest intelligence that is available to human [5]. Accepting the idea of non-violence as a profound practice of life is difficult for most of us.

Riane Eisler, a cultural historian, and Walter Wink, a theologian, mention that over the last 10,000 years societies around the world have been built on a model of domination that uses the language of violence, applies ways of thinking and strategies to influence themselves and others (to dominate), as opposed to a second social system - a partnership model called a life-enriching system [5].

NVC helps the doctor to meet the patient's needs because of his or her concern, not because of fear of criticism, threat of punishment, avoidance of guilt or shame. A doctor's empathy for a patient is the ability to come into contact with their feelings and needs. The language of life (living language) perceives the doctor's empathy towards themselves as equally important. By equipping with specific tools, NVC helps to cope with stress and thus reduces the risk of professional burnout, which in the case of a doctor and stressful conditions in which they often work, seems to be extremely valuable.

\section{Non-violent communication in doctor- patient relationship}

A good doctor-patient relationship is an important part of patient treatment. It also brings many benefits for the doctor, therefore, assimilating assumptions and practicing the ability to communicate in the language of life is very valuable and brings with it what the doctor is working on - making the world a better place $[6,7]$. One of NVC tools are 4 steps - elements that help to formulate statements that increase the chance of contact and understanding between people; they are extremely useful in the doctor-patient contact:

1. Observation.

2. Feeling.

3. Need.

4. Request.

At this point, it seems extremely important to stress that the use of these elements in the communication process is aimed at achieving contact and understanding between the doctor and the patient. NVC recognises free will and choice as essential needs of every human being and for this reason this model is not intended to be used for forcing, manipulating, judging and criticising.

It seems important to note the existence of three possible paths using these 4 steps. The first one is self-empathy, which enables the subject to discern their own emotions and feelings, especially useful when the doctor encounters a stressful situation in which strong such feelings as anger, powerlessness or one they have not met before and do not know how to react. Thanks to a thorough analysis of the stimulus, experienced emotions and resulting needs, the physician is usually able to formulate a number of requests from which they can choose the one that best helps them to take care of named needs. The next path is self-expression - the subject, e.g. a physician, expresses in one or more sentences a kind of summary of the process of empathy towards oneself, keeping all or some elements of 4 steps, depending on the situation. The self-expression may end the conversation or be an invitation for another person to a dialogue. The next path is empathy towards others - the subject reads the other person's emotions and needs, as well as what he or she cares about (his or her request). For example, the doctor may discern how the patient who has come to visit them feels and what he or she needs. The patient frequently wants to protect their health and needs support. However, as mentioned before, there are different strategies for how to meet these needs.

Rosenberg's concept assumes to acquire the ability to formulate observations, refraining from a judgment or evaluation - a factual statement of what is happening, what I or another person is doing, e.g. the patient depending on which path we choose, then noticing his or her feelings, e.g. dismay, uncertainty, 
fear. Feelings have an informative function, which makes it easier to identify needs. In the last step the request that the doctor has or the one the patient addresses to the doctor becomes specified.

Separation of individual elements serves the purpose of learning, makes it easier for the doctor to improve the technique and gives more clarity in the process of communication; over time they are combined into a whole. Thanks to NVC, the doctor gets rid of habits that have activated e.g. in contact with the statement made by the patient, which the doctor has perceived as a critical assessment and which previously ordered the doctor to defend himself by withdrawal or attack. The doctor starts to see both himself / herself and the patient in a new light, as well as their and patient's intentions and the relationship that exists between them. Resistance, defensive attitude and violent reactions of the doctor are increasingly less common because the patient is perceived through their intentions, not through words that may be awkward in a given situation. If the doctor focuses on clear expressing of their observations and needs, instead of judging, they will find it much easier to cope with situations that have so far been challenging for them. From NVC point of view, it is extremely important to listen to both the patient and oneself [5]. The essential assumption, common with the ones of systemic family therapies, that every message is an expression of some need. If the doctor makes such an assumption, they can practice in understanding the meaning of various statements and messages. It is important to build a more human image of human in your consciousness. When we become aware of the humanity that binds us all together and when we recognise ourselves in this context, then capacity for compassion is born in us.

\section{Observation - perception without judging or evaluation}

Our brain, in order not to get lost in a multitude of information reaching us, often groups it into cognitive patterns and gives it the so-called labels. Selecting the data coming from the world, according to the key that is subconsciously choosen by our brain, is a biological principle. We get an incomplete, filtered by our cognitive system, picture of the other person (or situation), more or less close to reality. Our way of thinking is usually an unconscious process, and change starts with becoming aware of it. NVC, based on the assumption that the mind shapes the perception of reality, helps the doctor to increase awareness [8]. Observation gives a different perspective from the way of thinking based on judgments, evaluations and labels. If a doctor finds their judging thoughts, words and behavior, they can change and improve their relationship with both the patient and themselves. According to the NVC model, the doctor first observes what has happened, e.g. what the patient specifically did or said, separating observations from interpretations and judgments. The doctor will tell what the camera would record, not what meaning it gives to a given situation or given words. In the latter case, i.e. when the doctor actually bases on their own interpretations and judgements, the patient may hear mainly blaming and criticism.

\section{Feelings - their recognizing and expressing}

The doctor can choose one of two paths: either to focus on themselves (their own feelings and needs) showing self-empathy, or to try to understand the patient (to see the patient's feelings and needs), i.e. to show empathy towards the patient. The physician may name for themselves their feelings that have arisen in connection with a given situation. Something has happened and they start to feel something. What they feel, not something else, comes from his unmet or satisfied needs, about which more will be written below - in step three. The doctor may ask themselves: what did I feel then? In the NVC language, the words by which feelings are expressed are distinguished from words and sentences which contain the interpretation of someone else's behaviour and description of our thoughts.

\section{Needs - linking currently experienced feelings to values}

Needs in psychology are often defined as a kind of motivation to act. Rosenberg defines them as a kind of resource that sustains our lives and puts them at the centre of attention of NVC [9]. For example, a patient needs air, water, rest and food to feel physically well. The patient's mental and spiritual well-being will most likely improve when the need for understanding, belonging or recognition is satisfied. A similar mechanism applies to the doctor's needs: We all have the same needs regardless of gender, level of education, religious beliefs, or nationality. What distinguishes a doctor from a patient - a given person from another - are strategies, ways of behaviour, e.g. requirements, requests, desires, and solutions they choose to satisfy a given need. At the level of strategy, people easily fall into conflict, while at the level of needs it is impossible [9]. How to distinguish one from the other? Needs are universal, everyone has the same 
Table 1. Feelings and needs with regard to patients' statements

\begin{tabular}{|c|c|c|c|c|}
\hline Cancer patients' statements & Patient's feelings & Patient's needs & Doctor's feelings & Doctor's needs \\
\hline $\begin{array}{l}\text { That is impossible! It cannot be } \\
\text { cancer, there is probably some } \\
\text { kind of misdiagnosis - there is } \\
\text { definitely some other explana- } \\
\text { tion for my symptoms }\end{array}$ & $\begin{array}{l}\text { Surprise, astonish- } \\
\text { ment, overwhelm- } \\
\text { ment, fear }\end{array}$ & $\begin{array}{l}\text { Explanation, under- } \\
\text { standing, security, } \\
\text { comfort, calmness, } \\
\text { hope }\end{array}$ & $\begin{array}{l}\text { Dejection, con- } \\
\text { fusion, embarrass- } \\
\text { ment, powerles- } \\
\text { sness }\end{array}$ & $\begin{array}{l}\text { Trust, contact, to } \\
\text { be heard }\end{array}$ \\
\hline $\begin{array}{l}\text { Why did this happen to me? } \\
\text { That is not fair! }\end{array}$ & $\begin{array}{l}\text { Frustration, } \\
\text { disappointment, } \\
\text { irritation, anger, } \\
\text { resentment }\end{array}$ & $\begin{array}{l}\text { Trust, equal oppor- } \\
\text { tunities, empathy, } \\
\text { understanding and } \\
\text { being understood }\end{array}$ & $\begin{array}{l}\text { Sadness, impa- } \\
\text { tience, overwhel- } \\
\text { mment }\end{array}$ & $\begin{array}{l}\text { Authenticity, } \\
\text { simplicity }\end{array}$ \\
\hline $\begin{array}{l}\text { But maybe if I start eating he- } \\
\text { althy now, and do some sports, } \\
\text { lose weight, and quit smoking, } \\
\text { the disease will go away }\end{array}$ & $\begin{array}{l}\text { Fear, agitation, } \\
\text { openness }\end{array}$ & $\begin{array}{l}\text { Confidence, support, } \\
\text { hope, a sense of } \\
\text { empowerment and } \\
\text { influence over own } \\
\text { life, physical safety }\end{array}$ & $\begin{array}{l}\text { Loneliness, } \\
\text { embarrassment, } \\
\text { tension, }\end{array}$ & $\begin{array}{l}\text { Clarity, coopera- } \\
\text { tion, contribu- } \\
\text { tion }\end{array}$ \\
\hline $\begin{array}{l}\text { Nothing makes sense anymore! } \\
\text { There is no need for therapy } \\
\text { now, I am going to die soon } \\
\text { anyway... }\end{array}$ & $\begin{array}{l}\text { Desperation, } \\
\text { apathy, dejection, } \\
\text { dullness }\end{array}$ & $\begin{array}{l}\text { Explanation, re- } \\
\text { assurance, trust, } \\
\text { purpose, stimulation, } \\
\text { animation }\end{array}$ & $\begin{array}{l}\text { Fearfulness, } \\
\text { powerlessness, } \\
\text { sadness, impa- } \\
\text { tience }\end{array}$ & $\begin{array}{l}\text { Contributing to } \\
\text { enrich life, fe- } \\
\text { edback, support, } \\
\text { encouragement }\end{array}$ \\
\hline
\end{tabular}

regardless of age, culture or gender. While strategies are more concrete, they provide information: what, who, when or where.

Many people cannot express their own needs and are not ready to understand the needs of the other party. However, everyone can learn to distinguish needs from strategies. The doctor may be wondering: what need of his or her patient is unfulfilled or fulfilled? What is important? What do I want? We need to remember, however, that one need can be satisfied by many different strategies, but one strategy can also satisfy many different needs. Therefore, when a patient does something, it is worth asking about the motives for this action and the needs behind it, as such approach leads to the increase in mutual understanding.

\section{Requests - formulating concrete requests instead of demands}

Asking yourself the following questions can help you formulate your requests:

- Is there anything I would like to ask someone now?

- Do I want to ask for something for myself?

In the fourth step, please remember to make a request, not a demand. How to distinguish one from the other? Most often, it is only when the patient refuses that the distinction between the two is possible. If the doctor gets nervous, offended or starts complaining, it means that he/she assumed in advance that the patient would do what the doctor said, which, in turn, in NVC means that a demand rather than request had been made. Requests should be clear and concrete, indicating what, where and when is requested. It is important that the request is feasible and indicates what the doctor wants instead of what he/she does not want.

If the doctor thinks he/she is going to meet a difficult patient, it is worthwhile for him to start preparing to talk to the patient with self-empathy, because when he/she establishes what exactly happened (observation), what he/she feels (feelings), what need he/she is talking about (needs) and what he/she can ask (someone or himself/herself) to satisfy those needs (formulate a request), he/she will know faster what he/she wants to do about it. Will the doctor want to tell the patient about his/her feelings and needs, or will he/she be willing to listen to the patient and try to understand the patient; to see with "his/her eyes" how the patient sees the situation, what the patient feels and needs. Regardless of what the doctor chooses to do, he/she can always return to the path of self-empathy (Table 1).

\section{Summary}

So far, few studies concerning the use of NVC in patient care concerned psychiatric patients, men with addictions undergoing treatment, conditionally released and empathic communication in the delivery room in relation to parturients, chronic infectious diseases, as well as teaching communication between doctors [10-19]. Palliative care doctors may experience a sense of powerlessness, including also a dislike for patients who cannot be helped [20], which is one of the key elements of professional burnout, which has often been associated with decreasing empathy among health care workers [20-22]. 
The Rosenberg model aids communication skills, improves the understanding between the doctor and the patient and the quality of this relationship, influences the doctor's satisfaction with work, leads to a better attitude and, consequently, better treatment of patients, and potentially helps avoiding professional burnout [1]. The practice of NVC stimulates "giving from the heart", enables the achievement of one of the life goals, which is the development and achievement of true and full humanity by a doctor to the best of his/her abilities [8]. Such communication also improves the awareness and quality of life of patients referred to palliative care [3].

\section{Declaration of conflict of interests}

The authors declare that there is no conflict of interest.

\section{Funding}

This manuscript has no funding.

\section{References}

1. Wieczorek Z. Porozumienie bez przemocy Marshalla Rosenberga jako sposób na redukowanie barier komunikacyjnych. Przegląd Naukowo-Metodyczny. Edukacja dla Bezpieczeństwa. 2012; 3: 103-116.

2. Nowaczyk K, Stanisić MG, Rzepa T. Staż pracy i płeć lekarza, a efektywność komunikowania się z pacjentem. Med Rodz. 2016; 19(2): 55-58.

3. Gradalski T, Wesolek E, Kleja J. Terminal cancer patients' informed consent for palliative care admission and their quality of life. J Palliat Med. 2012; 15(8): 847, doi: 10.1089/jpm.2012.0055, indexed in Pubmed: 22849597.

4. Kashtan M. Niezwykle świadome życie. NVC Zone sp. z o.o., Poznań 2018.

5. Rosenberg MB. Porozumienie bez przemocy. O języku serca. J Santorski \& Co, Warsaw 2003.

6. Grzesiuk L, Trzebińska E. Jak ludzie porozumiewają się? Instytut Wydawniczy Nasza Księgarnia, Warsaw 1978.

7. Mayerscough PR, Ford M. Jak rozmawiać z pacjentem? Wydawnictwo Psychologiczne, Gdańsk 2001.

8. Angelis B. Prawdy o życiu. Książnica Publishing House, Katowice 2001.

9. Rosenberg MBW. świecie porozumienia bez przemocy. MiND Publishing House, Podkowa Leśna 2013.
10. Lee M, Lee SB. Effects of Nonviolent Communication(NVC) Program consist of Communication Ability, Relationship and Anger in Nurses. Journal of the Korea Society of Computer and Information. 2016; 21(10): 85-89, doi: 10.9708/jksci.2016.21.10.085.

11. Rosenberg M, Molho P. Nonviolent (empathic) communication for health care providers. Haemophilia. 1998; 4(4): 335-340, doi: 10.1046/j.1365-2516.1998.440335.x, indexed in Pubmed: 9873751.

12. Museux AC, Dumont $S$, Careau $E$, et al. Improving interprofessional collaboration: The effect of training in nonviolent communication. Soc Work Health Care. 2016; 55(6): 427-439, doi: 10.1080/00981389.2016.1164270, indexed in Pubmed: 27116417.

13. Wacker R, Dziobek I. Preventing empathic distress and social stressors at work through nonviolent communication training: A field study with health professionals. J Occup Health Psychol. 2018; 23(1): 141-150, doi: 10.1037/ocp0000058, indexed in Pubmed: 27977228.

14. Baranowska B, Doroszewska A. Porozumienie bez przemocy. Jak wykorzystać empatyczną komunikację na sali porodowej? Zdrowie Publiczne i Zarządzanie. 2018; 16(4): 241-246, doi: 10.4467/20842627oz.18.027.10565.

15. Nosek M. Nonviolent communication: a dialogical retrieval of the ethic of authenticity. Nurs Ethics. 2012; 19(6): 829-837, doi: 10.1177/0969733012447016, indexed in Pubmed: 22717406.

16. MarlowE, Nyamathi A, Grajeda WT, et al. Nonviolent communication training and empathy in male parolees. J Correct Health Care. 2012; 18(1): 8-19, doi: 10.1177/1078345811420979, indexed in Pubmed: 22095007.

17. Sears M. Humanizing Health Care with Nonviolent Communication. Universe, New York 2006.

18. Sears M. Humanizing Health Care Creating Cultures of Compassion with Nonviolent Communication Puddle Dancer Press. Encinitas 2010.

19. Beard J, Beard D, English E. A new communication skills course for junior doctors. Med Educ. 2009; 43(5): 496-497, doi: 10.1111/j.1365-2923.2009.03339.x, indexed in Pubmed: 19422517.

20. Ekman E. Development, delivery and evaluation of a pilot stress reduction, emotion regulation, and mindfulness training for juvenile justice officers. J Juvenile Justice. 2015; 4: 71.

21. Maslach C, Schaufeli WB, Leiter MP. Job burnout. Annu Rev Psychol. 2001; 52: 397-422, doi: 10.1146/annurev. psych.52.1.397, indexed in Pubmed: 11148311.

22. West CP, Huschka MM, Novotny PJ, et al. Association of perceived medical errors with resident distress and empathy: a prospective longitudinal study. JAMA. 2006; 296(9): 1071-1078, doi: 10.1001/jama.296.9.1071, indexed in Pubmed: 16954486. 


\section{Porozumienie bez przemocy Marshalla Rosenberga jako język życia w relacji lekarz-pacjent}

Artykuł jest tłumaczeniem pracy: Gęsińska H., Hołyń B., Nowakowska-Arendt A., Krajnik M., Marshall Rosenberg's non-violent communication as the language of life in a doctor-patient relationship. Palliat. Med. Pract. 2020, tom 14, nr 4: $285-289$. Należy cytować wersję pierwotną.

\section{Streszczenie}

Celem artykułu było przedstawienie koncepcji porozumienia bez przemocy (PBP [NVC, Nonviolent Communication]) Marshalla Bertranda Rosenberga i przydatności w relacji lekarz-pacjent. M. B. Rosenberg koncepcję PBP oparł na założeniu, że naturalną zdolnością człowieka jest empatia skierowana do innych ludzi i do siebie samego. Nasza kultura tłumi jednak te naturalne zdolności. Język proponuje wiele wyrażeń, które blokują naturalne współodczuwanie, ponieważ przesycone są osądami moralnymi, oceniającymi porównaniami, karami, wzbudzaniem poczucia winy czy wstydu. Autor PBP proponuje czterofazowy model empatycznej komunikacji bez przemocy i manipulacji, który stanowi podstawę zmian procesu myślowego: obserwowanie bez osądzania, rozpoznawanie, wiązanie aktualnie przeżywanych uczuć z potrzebami (wartościami) i formułowanie konkretnych próśb zamiast żądań.

Palliat Med Pract 2020; 14, 4: 290-294

Słowa kluczowe: porozumienie bez przemocy, empatia, komunikacja lekarz-pacjent, uczucia, potrzeby

\section{Wstęp}

Przekonanie, że wystarczy wieloletnie doświadczenie pracy lekarza z pacjentami, aby nauczyć się zrozumiale komunikować i radzić sobie w trudnych sytuacjach nie znajduje potwierdzenia w rzeczywistości. Brak znajomości założeń, niezbędnych do stosowania dobrej komunikacji na początku drogi zawodowej i brak rozwoju w tym względzie skutkują popełnianiem błędów komunikacyjnych, które przez lata pracy utrwalają się, wzmacniają i ostatecznie mogą doprowadzić do wypalenia zawodowego oraz przekonania, że pacjenci, z którymi kontaktuje się są wyjątkowo trudni [1]. Nowa- czyk i wsp. wykazali, że efektywność komunikowania lekarzy zmniejsza się wraz ze stażem pracy [2].

Sören Kierkegaard napisał: „Jeżeli chcę doprowadzić człowieka do pewnego określonego celu, muszę najpierw spotkać go w tym miejscu, gdzie on się znajduje i zacząć właśnie tam. Ten, kto tej umiejętności nie posiada oszukuje się, myśląc, że potrafi pomóc ludziom. Po to, żeby komuś pomóc, muszę wprawdzie rozumieć więcej niż on, ale przede wszystkim muszę rozumieć to, co on rozumie. Jeśli tego nie umiem, nie pomoże to, że potrafię i wiem więcej. A jeśli chcę pokazać, ile umiem oznacza to, że się wynoszę i jestem próżny i w gruncie rzeczy chcę być podziwiany przez drugiego, zamiast

\footnotetext{
Adres do korespondencji:

Hanna Gęsińska

Uniwersytet Mikołaja Kopernika w Toruniu, Collegium Medicum w Bydgoszczy, Polska ul. Jagiellońska 13/15, 85-067 Bydgoszcz

e-mail: hannagesinska1@cm.umk.pl
} 
mu pomagać. Każda prawdziwa pomoc zaczyna się od pokory wobec tego, komu chcę pomóc i dlatego muszę pamiętać, że pomoc nie polega na woli panowania nad kimś, lecz na pragnieniu, aby mu służyć. Jeśli tego nie wiem, nie mogę też nikomu pomóc" [3].

„Edukować umysł bez edukacji serca, to jak w ogóle nie edukować" stwierdził Arystoteles w IV wieku p.n.e. Naprzeciw tej prawdzie wyszedł Marshall Bertram Rosenberg amerykański psycholog, który w latach sześćdziesiątych XX wieku zaproponował proces porozumienia bez przemocy (PBP [NVC, Nonviolent Communication]) w celu wdrożenia postanowienia o niestosowaniu przemocy na wszystkich poziomach naszej struktury: w myślach, słowach i działaniach [4]. Ponieważ nazwa PBP jest chroniona znakiem towarowym i mogą jej używać wyłącznie certyfikowani trenerzy NVC przez organizację założoną przez M.B. Rosenberga - Center for Nonviolent Communiction (CNVC) - często także nazywane jest językiem życia czy językiem serca. Stosowanie języka życia wymaga modyfikacji myślenia, jako warunku niezbędnego do poprawnej komunikacji.

Lekarze zdają sobie sprawę $\mathrm{z}$ istnienia przemocy werbalnej, ale już nie wszyscy wiedzą, że przejawem stosowania przemocy jest zrzucanie odpowiedzialności, osąd moralny, porównywanie, karanie czy zmuszanie. Więcej osób potrafi wyzbyć się przemocy fizycznej, natomiast nie potrafi zrezygnować z języka osądów, gróźb czy żądań. Podobnie, znacznie więcej osób zdoła wyćwiczyć swój język niż wytrenować swój umysł czy serce tak, aby wytrwać w postanowieniu o niestosowaniu przemocy [4]. Nasze słowa odzwierciedlają nasze myśli, to o czym myślimy i jak myślimy. Hinduski filozof Jiddu Krishnamurti stwierdził, że dokonywanie spostrzeżeń, przy równoczesnym powstrzymywaniu się od ocen, dowodzi najwyższej inteligencji, jaka dostępna jest człowiekowi [5]. Przyjęcie idei niestosowania przemocy, jako głębokiej praktyki życia jest trudne dla większości z nas.

Historyk kultury Riane Eisler i teolog Walter Wink wspominają, że w okresie ostatnich 10 tysięcy lat na całym świecie zbudowane zostały społeczeństwa oparte na modelu dominacji, który używa języka przemocy, stosuje sposoby myślenia i strategie, aby mieć wpływ na siebie i innych (aby dominować), w przeciwieństwie do drugiego systemu społecznego - modelu partnerskiego nazywanego systemem wzbogacającym życie [5].

Porozumienie bez przemocy pomaga lekarzowi zaspokajać potrzeby pacjenta z troski o niego, nie zaś z powodu lęku przed krytyką, groźbą kary, uniknięcia poczucia winy czy wstydu. Empatia lekarza do pacjenta to umiejętność nawiązania kontaktu z jego uczuciami i potrzebami. Język życia (żywy język) za równie istot- ną postrzega empatię lekarza wobec siebie samego. Porozumienie bez przemocy wyposażając w konkretne narzędzia, pomaga radzić sobie ze stresem, a tym samym zmniejsza ryzyko wypalenia zawodowego, co w przypadku lekarza i stresujących warunków, w jakich często pracuje, wydaje się być niezwykle cenne.

\section{Porozumienie bez przemocy w relacji lekarza z chorym}

Dobra relacja lekarz-pacjent stanowi istotny element leczenia pacjenta, przynosi również wiele korzyści lekarzowi, dlatego przyswojenie założeń i praktykowanie umiejętności komunikowania się językiem życia jest bardzo wartościowe i niesie ze sobą to nad czym lekarz pracuje - uczynienie świata lepszym [6, 7]. Jednym z narzędzi PBP są cztery kroki - elementy, które pomagają w sformułowaniu wypowiedzi zwiększającej szansę na kontakt i zrozumienie pomiędzy ludźmi i są niezwykle przydatne w kontakcie lekarza z pacjentem:

1. obserwacja,

2. uczucie,

3. potrzeba,

4. prośba.

Niezwykle ważne wydaje się w tym miejscu podkreślenie, że zastosowanie wymienionych elementów w procesie komunikacji ma na celu uzyskanie kontaktu i zrozumienia pomiędzy lekarzem i pacjentem. Porozumienie bez przemocy uznaje wolną wolę i wybór, jako istotne potrzeby przynależne każdemu człowiekowi i z tego powodu model ten w założeniach PBP nie służy do zmuszania, manipulacji, oceniania i krytykowania.

Istotne wydaje się być zwrócenie uwagi na istnienie trzech możliwych ścieżek, w których wykorzystane zostają wymienione cztery kroki. Pierwszą z nich jest empatia dla siebie, która umożliwia rozeznanie w posiadanych przez podmiot emocjach i uczuciach, przydatna zwłaszcza, kiedy lekarz napotyka sytuację stresową, w której pojawiają się silne uczucia, takie jak złość, bezsilność, lub taką, z którą wcześniej się nie spotkał i nie wie, jak ma zareagować. Dzięki wnikliwej analizie bodźca, doświadczanych emocji i wynikających z nich potrzeb jest w stanie zazwyczaj sformułować kilka próśb, z których może wybrać tę, która najlepiej pomoże mu zatroszczyć się o nazwane potrzeby. Kolejną ścieżką jest wyrażenie siebie — podmiot, na przykład lekarz wyraża w jednym lub kilku zdaniach to, co jest pewnego rodzaju podsumowaniem procesu empatii dla siebie, zachowując wszystkie lub niektóre elementy 4 kroków w zależności od sytuacji. Wyrażenie siebie może kończyć rozmowę lub być zaproszeniem drugiej osoby do dialogu. Następną ścieżką jest empatia dla drugiej osoby - podmiot odczytuje emocje i potrzeby drugiej osoby, a także to, na 
czym jej zależy (jej prośbę). Przykładowo lekarz może rozeznać jak czuje się i czego potrzebuje pacjent, który przyszedł do niego na wizytę. Często pacjent chce chronić swoje zdrowie i potrzebuje wsparcia - na sposób realizacji tych potrzeb istnieją jednak, jak już wcześniej wspomniano, różnorodne strategie.

Koncepcja Rosenberga zakłada nabywanie umiejętności formułowania obserwacji, powstrzymując się od osądu czy oceny: rzeczowego stwierdzenia, co się dzieje, co robię ja lub inna osoba, na przykład pacjent w zależności od tego, którą z wymienionych ścieżek wybierzemy, następnie zauważenie uczuć swoich lub tej drugiej osoby, na przykład przerażenie, niepewność, lęk. Uczucia pełnią funkcję informacyjną, dzięki nim łatwiej można określić potrzeby. W ostatnim etapie precyzowana jest prośba, jaką ma lekarz lub z jaką zwraca się do lekarza pacjent.

Oddzielenie poszczególnych elementów służy nauce, ułatwia lekarzowi doskonalenie techniki i daje większą jasność w procesie komunikacji, z czasem są one łączone w całość. Dzięki PBP lekarz pozbywa się nawyków, które uaktywniały się na przykład w zetknięciu ze stwierdzeniem wypowiedzianym przez pacjenta, a które lekarz odbierał jako krytyczną ocenę i które dotychczas nakazywały lekarzowi bronić się poprzez wycofanie lub atak. Lekarz zaczyna widzieć w nowym świetle zarówno siebie, jak i pacjenta, a także swoje i pacjenta intencje i istniejącą między nimi, wzajemną relację. Opór, postawa obronna i gwałtowne reakcje lekarza pojawiają się coraz rzadziej, ponieważ pacjent widziany jest poprzez swoje intencje, a nie słowa, które mogą być niezręczne $w$ danej sytuacji. Jeśli lekarz skoncentruje się na jasnym wyrażaniu obserwacji i potrzeb, zamiast na osądzaniu, stwierdzi, że jest mu o wiele łatwiej radzić sobie w sytuacjach, które dotychczas były dla niego wyzwaniem. $Z$ punktu widzenia PBP ogromnie istotne jest słuchanie zarówno pacjenta, jak i samego siebie [5]. Istotne jest założenie, wspólne z założeniami systemowych terapii rodzin, iż każdy komunikat jest wyrazem jakieś potrzeby. Jeżeli lekarz przyjmie takie założenie, może wyćwiczyć się w rozumieniu sensu różnych stwierdzeń i przekazów. Istotne jest zbudowanie w swojej świadomości bardziej ludzkiego obrazu człowieka. Kiedy uświadamiamy sobie łączące nas wszystkich człowieczeństwo i rozpoznajemy w tym kontekście samych siebie, wówczas rodzi się w nas zdolność współodczuwania.

\section{Observacja — spostrzeżenie bez osądzania i oceniania}

Nasz mózg, by nie pogubić się w wielości docierających do nas informacji, często porządkuje je w schematy poznawcze i nadaje im tak zwane etykiety. Selekcjonowanie docierających ze świata danych, zgodnie z kluczem, który podświadomie wybiera nasz mózg, to zasada biologiczna. Dociera do nas niepełny obraz drugiego człowieka czy sytuacji, bardziej lub mniej zbliżony do rzeczywistości, filtrowany przez nasz system poznawczy. Nasz sposób myślenia, to zwykle proces nieświadomy, a zmiana zaczyna się od uświadomienia go sobie. Porozumienie bez przemocy bazując na założeniu, że umysł kształtuje postrzeganie rzeczywistości, pomaga lekarzowi zwiększyć świadomość [8]. Obserwacja daje inną perspektywę niż sposób myślenia opierający się na osądach, ocenach i etykietach. Jeżeli lekarz zlokalizuje swoje oceniające myśli, słowa i zachowania, może dokonać zmiany i poprawić swoją relację zarówno z pacjentem, jak i ze sobą. Zgodnie z modelem PBP lekarz w pierwszym kroku obserwuje co się wydarzyło, na przykład co pacjent konkretnie zrobił lub powiedział, oddzielając obserwacje od interpretacji i osądów. Powie o tym, co nagrałaby kamera, a nie o tym, jakie znaczenie nadaje danej sytuacji czy danym słowom. W tym drugim przypadku, czyli kiedy lekarz tak naprawdę bazuje na swoich interpretacjach i osądach, pacjent może usłyszeć głównie obwinianie i krytykę.

\section{Uczucia - ich rozpoznawanie i wyrażanie}

Lekarz może wybrać jedną z dwóch ścieżek: albo skupić się na sobie (swoich uczuciach i potrzebach), okazując sobie empatię, albo próbować zrozumieć pacjenta (zobaczyć uczucia i potrzeby chorego), czyli okazać empatię pacjentowi. Lekarz może nazwać dla siebie swoje uczucia, które pojawiły się w związku z opisywaną sytuacją. Coś się wydarzyło, a on zaczyna coś czuć. Dlaczego czuje akurat to, a nie coś innego, wypływa z jego niezaspokojonych lub zaspokojonych potrzeb, o których więcej zostanie napisane poniżej - w kroku trzecim. Lekarz może zadać sobie pytanie: co wtedy poczułem/poczułam? W języku PBP słowa, którymi wyrażane są uczucia odróżnia się od słów i zdań, w których zawarta jest interpretacja cudzych zachowań i opis naszych myśli.

\section{Potrzeby — wiązanie aktualnie przeżywanych uczuć z wartościami}

Potrzeby w psychologii często definiowane są jako pewnego rodzaju motywacje skłaniające nas do działania. Rosenberg definiuje je jako swego rodzaju zasoby, które podtrzymują nasze życie i stawia je w centrum zainteresowania PBP [9]. Na przykład, aby pacjent dobrze się czuł pod względem fizycznym potrzebuje powietrza, wody, odpoczynku i pożywienia. Jego psychiczne i duchowe samopoczucie najprawdopodobniej 
poprawi się wówczas, kiedy zaspokojona zostanie jego potrzeba zrozumienia, przynależności czy uznania. Analogicznie jest z potrzebami lekarza. Wszyscy mamy jednakowe potrzeby bez względu na płeć, poziom wykształcenia, przekonania religijne czy narodowość. Tym, co różni lekarza od pacjenta — danego człowieka od drugiego, są strategie, sposoby zachowania, na przykład wymagania, prośby, pragnienia, rozwiązania, które wybierają, aby zaspokoić daną potrzebę. Na poziomie strategii ludzie łatwo popadają w konflikt, zaś na poziomie potrzeb jest to niemożliwe [9]. Jak odróżnić jedno od drugiego? Potrzeby są uniwersalne, każdy ma takie same bez względu na wiek, kulturę czy płeć. Strategie natomiast są bardziej konkretne, niosą w sobie informację: co, kto, kiedy lub gdzie.

Wiele osób nie potrafi wyrażać własnych potrzeb i nie posiada gotowości zrozumienia potrzeb drugiej strony. Każdy jednak może nauczyć się odróżniać potrzeby od strategii. Lekarz może zastanawiać się, zadając sobie pytania: jaka jego lub pacjenta potrzeba pozostała niespełniona lub spełniona? co jest ważne? czego chcę? Pamiętajmy, że jedną potrzebę można zaspokoić przez wiele różnych strategii, ale też jedna strategia może zaspokajać wiele różnych potrzeb. Dlatego też, kiedy pacjent coś robi, warto pytać o motywy tego działania i o to, jakie potrzeby stoją za tym działaniem, wówczas zwiększa się wzajemne zrozumienie.

\section{Prośby — formułowanie konkretnych próśb zamiast żądań}

W formułowaniu próśb może pomóc zadanie sobie następujących pytań:
- Czy jest coś, o co chciałem/chciałbym kogoś teraz poprosić?

- Czy chcę poprosić o coś siebie?

Przy czwartym kroku należy pamiętać o tym, aby prośba była prośbą, a nie żądaniem. Po czym to poznać? Najczęściej udaje się odróżnić jedno od drugiego dopiero wówczas, kiedy pacjent odmówi. Jeśli lekarz się zdenerwuje, obrazi lub zacznie narzekać, to znaczy, że z góry założył, że pacjent zrobi to, co powiedział lekarz, co z kolei w PBP oznacza, że żąda, a nie prosi. Prośby warto wyrażać w sposób jasny i konkretny: co, gdzie i kiedy. Ważne, aby prośba była realna do spełnienia i by mówiła, czego chce lekarz, a nie czego nie chce.

Jeżeli lekarz myśli, że czeka go spotkanie z trudnym pacjentem, warto, aby przygotowanie do rozmowy z pacjentem zaczynał od empatii dla siebie, ponieważ kiedy ustali, co konkretnie się wydarzyło (obserwacja), co w związku z tym czuje (uczucia), o jakiej potrzebie te uczucia mówią (potrzeby) i o co może poprosić (kogoś lub siebie), by te potrzeby zaspokoić (sformułuje prośbę), to szybciej będzie wiedzieć, jakie działania w związku z tym chce podjąć. Czy zechce powiedzieć pacjentowi o swoich uczuciach i potrzebach, czy może będzie miał gotowość wysłuchania pacjenta i spróbuje go zrozumieć; zobaczyć „jego oczami” jak on widzi tę sytuację, co czuje i czego potrzebuje. Niezależnie od tego na co się lekarz zdecyduje, zawsze może wrócić do ścieżki empatii dla siebie (tab. 1).

\section{Podsumowanie}

Dotychczasowe, nieliczne badania dotyczące stosowania metody PBP w opiece nad pacjentami doty-

Tabela 1. Uczucia i potrzeby w odniesieniu do wypowiedzi pacjentów

\begin{tabular}{|c|c|c|c|c|}
\hline Wypowiedzi chorych na nowotwory & Uczucia pacjenta & Potrzeby pacjenta & Uczucia lekarza & Potrzeby lekarza \\
\hline $\begin{array}{l}\text { To niemożliwe! To nie może być rak, } \\
\text { pewnie jest jakaś pomyłka w dia- } \\
\text { gnozie - na pewno jest jakieś inne } \\
\text { wytłumaczenie moich dolegliwości }\end{array}$ & $\begin{array}{l}\text { Zaskoczenie, } \\
\text { zdziwienie, } \\
\text { przytłoczenie, } \\
\text { wystraszenie }\end{array}$ & $\begin{array}{l}\text { Sensu, zrozumie- } \\
\text { nia, bezpieczeń- } \\
\text { stwa, komfortu, } \\
\text { spokoju, nadziei }\end{array}$ & $\begin{array}{l}\text { Zniechęcenie, } \\
\text { zmieszanie, } \\
\text { zażenowanie, } \\
\text { bezsilność }\end{array}$ & $\begin{array}{l}\text { Zaufania, kontak- } \\
\text { tu, bycia słysza- } \\
\text { nym }\end{array}$ \\
\hline $\begin{array}{l}\text { Dlaczego akurat mnie to spotkało? } \\
\text { To niesprawiedliwe! }\end{array}$ & $\begin{array}{l}\text { Frustracja, } \\
\text { rozczarowanie, } \\
\text { poirytowanie, } \\
\text { gniew, złość }\end{array}$ & $\begin{array}{l}\text { Zaufania, równych } \\
\text { szans, empatii, } \\
\text { zrozumienia i bycia } \\
\text { zrozumianym }\end{array}$ & $\begin{array}{l}\text { Smutek, znie- } \\
\text { cierpliwienie, } \\
\text { przytłoczenie }\end{array}$ & $\begin{array}{l}\text { Autentyczności, } \\
\text { tatwości }\end{array}$ \\
\hline $\begin{array}{l}\text { A może, jeżeli teraz zacznę zdro- } \\
\text { wo się odżywiać, uprawiać sport, } \\
\text { schudnę, rzucę palenie, to choroba } \\
\text { cofnie się }\end{array}$ & $\begin{array}{l}\text { Wystraszenie, } \\
\text { ożywienie, } \\
\text { otwartość }\end{array}$ & $\begin{array}{l}\text { Otuchy, wsparcia, } \\
\text { nadziei, poczu- } \\
\text { cia sprawczości i } \\
\text { wpływu na swoje } \\
\text { życie, bezpieczeń- } \\
\text { stwa fizycznego }\end{array}$ & $\begin{array}{l}\text { Samotność, } \\
\text { zażenowanie, } \\
\text { napięcie }\end{array}$ & $\begin{array}{l}\text { Jasności, współ- } \\
\text { pracy, wkładu }\end{array}$ \\
\hline $\begin{array}{l}\text { Nic już nie ma sensu! Nie ma po, co } \\
\text { się leczyć, przecież i tak niedługo } \\
\text { umrę... }\end{array}$ & $\begin{array}{l}\text { Desperacja, apa- } \\
\text { tia, zniechęcenie, } \\
\text { przygaszenie }\end{array}$ & $\begin{array}{l}\text { Sensu, otuchy, } \\
\text { zaufania, celu, } \\
\text { stymulacji, pobu- } \\
\text { dzenia }\end{array}$ & $\begin{array}{l}\text { Pełen obaw, } \\
\text { bezsilność, smu- } \\
\text { tek, zniecierpli- } \\
\text { wienie }\end{array}$ & $\begin{array}{l}\text { Przyczyniania się } \\
\text { do wzbogacania } \\
\text { życia, informacji } \\
\text { zwrotnej, wspar- } \\
\text { cia, otuchy }\end{array}$ \\
\hline
\end{tabular}


czyły chorych leczonych psychiatrycznie, mężczyzn uzależnionych poddanych leczeniu, warunkowo zwolnionych i empatycznej komunikacji na sali porodowej $w$ relacji z rodzącymi pacjentkami, z przewlekle chorymi na choroby zakaźne, a także nauczania komunikacji lekarzy [10-19]. Lekarze opieki paliatywnej doznając poczucia bezsilności, mogą doświadczać między innymi niechęci do pacjentów, którym nie mogą pomóc [20], która jest jednym z kluczowych elementów wypalenia zawodowego, któremu często przypisywano zmniejszenie empatii wśród pracowników ochrony zdrowia [20-22].

Model Rosenberga zwiększa umiejętności komunikowania się, poprawia zrozumienie pomiędzy lekarzem a pacjentem i jakość tej relacji, wpływa na zadowolenie lekarza z wykonywanej pracy, lepsze nastawienie i w konsekwencji lepsze traktowanie pacjentów, być może uniknięcie wypalenia zawodowego [1]. Praktykowanie PBP pobudza do „dawania $z$ serca", umożliwia realizowanie jednego z celów życia, jakim jest rozwój i osiągnięcie pełni człowieczeństwa przez lekarza na miarę jego możliwości [8]. Taka komunikacja poprawia także świadomość i jakość życia pacjentów kierowanych do opieki paliatywnej [3].

\section{Deklaracja konfliktu interesów}

Autorzy oświadczają, że nie występuje konflikt interesów.

\section{Finansowanie \\ Manuskrypt nie był finansowany.}

\section{Piśmiennictwo}

1. Wieczorek Z. Porozumienie bez przemocy Marshalla Rosenberga jako sposób na redukowanie barier komunikacyjnych. Przegląd Naukowo-Metodyczny. Edukacja dla Bezpieczeństwa. 2012; 3: 103-116.

2. Nowaczyk K, Stanisić MG, Rzepa T. Staż pracy i płeć lekarza, a efektywność komunikowania się z pacjentem. Med Rodz. 2016; 19(2): 55-58.

3. Gradalski T, Wesolek E, Kleja J. Terminal cancer patients' informed consent for palliative care admission and their quality of life. J Palliat Med. 2012; 15(8): 847, doi: 10.1089/jpm.2012.0055, indexed in Pubmed: 22849597.

4. Kashtan M. Niezwykle świadome życie. NVC Zone sp. z o.o., Poznań 2018.

5. Rosenberg MB. Porozumienie bez przemocy. O języku serca. J Santorski \& Co, Warsaw 2003.

6. Grzesiuk L, Trzebińska E. Jak ludzie porozumiewają się? Instytut Wydawniczy Nasza Księgarnia, Warsaw 1978.
7. Mayerscough PR, Ford M. Jak rozmawiać z pacjentem? Wydawnictwo Psychologiczne, Gdańsk 2001.

8. Angelis B. Prawdy o życiu. Książnica Publishing House, Katowice 2001.

9. Rosenberg MBW. świecie porozumienia bez przemocy. MiND Publishing House, Podkowa Leśna 2013.

10. Lee M, Lee SB. Effects of Nonviolent Communication(NVC) Program consist of Communication Ability, Relationship and Anger in Nurses. Journal of the Korea Society of Computer and Information. 2016; 21(10): 85-89, doi: 10.9708/jksci.2016.21.10.085.

11. Rosenberg M, Molho P. Nonviolent (empathic) communication for health care providers. Haemophilia. 1998; 4(4): 335-340, doi: 10.1046/j.1365-2516.1998.440335.x, indexed in Pubmed: 9873751.

12. Museux AC, Dumont $S$, Careau $E$, et al. Improving interprofessional collaboration: The effect of training in nonviolent communication. Soc Work Health Care. 2016; 55(6): 427-439, doi: 10.1080/00981389.2016.1164270, indexed in Pubmed: 27116417.

13. Wacker R, Dziobek I. Preventing empathic distress and social stressors at work through nonviolent communication training: A field study with health professionals. J Occup Health Psychol. 2018; 23(1): 141-150, doi: 10.1037/ocp0000058, indexed in Pubmed: 27977228.

14. Baranowska B, Doroszewska A. Porozumienie bez przemocy. Jak wykorzystać empatyczna komunikację na sali porodowej? Zdrowie Publiczne i Zarządzanie. 2018; 16(4): 241-246, doi: 10.4467/20842627oz.18.027.10565.

15. Nosek M. Nonviolent communication: a dialogical retrieval of the ethic of authenticity. Nurs Ethics. 2012; 19(6): 829-837, doi: 10.1177/0969733012447016, indexed in Pubmed: 22717406.

16. Marlow E, Nyamathi A, Grajeda WT, et al. Nonviolent communication training and empathy in male parolees. J Correct Health Care. 2012; 18(1): 8-19, doi: 10.1177/1078345811420979, indexed in Pubmed: 22095007.

17. Sears M. Humanizing Health Care with Nonviolent Communication. Universe, New York 2006.

18. Sears M. Humanizing Health Care Creating Cultures of Compassion with Nonviolent Communication Puddle Dancer Press. Encinitas 2010.

19. Beard J, Beard D, English E. A new communication skills course for junior doctors. Med Educ. 2009; 43(5): 496-497, doi: 10.1111/j.1365-2923.2009.03339.x, indexed in Pubmed: 19422517.

20. Ekman E. Development, delivery and evaluation of a pilot stress reduction, emotion regulation, and mindfulness training for juvenile justice officers. J Juvenile Justice. 2015; 4: 71.

21. Maslach C, Schaufeli WB, Leiter MP. Job burnout. Annu Rev Psychol. 2001; 52: 397-422, doi: 10.1146/annurev. psych.52.1.397, indexed in Pubmed: 11148311.

22. West CP, Huschka MM, Novotny PJ, et al. Association of perceived medical errors with resident distress and empathy: a prospective longitudinal study. JAMA. 2006; 296(9): 1071-1078, doi: 10.1001/jama.296.9.1071, indexed in Pubmed: 16954486. 